Research Paper

\title{
VEGFR-TKIs combined with chemotherapy for advanced non-small cell lung cancer: A systematic review
}

\author{
Lian Liu, Yue Zhang, Jia Wei, Zhaoxin Chen, Jing Yu ${ }^{\bowtie}$ \\ Cancer Center, Beijing Friendship Hospital, Capital Medical University, No. 95 Yong An Road, Xi Cheng District, Beijing, 100050, China. \\ $\triangle$ Corresponding author: Cancer Center, Beijing Friendship Hospital, Capital Medical University, No. 95 Yong An Road, Xicheng District, Beijing, 100050, \\ China. Phone: +86-10-63139326, Fax: +86-10-63139326. Email: yujing026@ccmu.edu.cn \\ (c) Ivyspring International Publisher. This is an open access article distributed under the terms of the Creative Commons Attribution (CC BY-NC) license \\ (https://creativecommons.org/licenses/by-nc/4.0/). See http://ivyspring.com/terms for full terms and conditions.
}

Received: 2018.09.01; Accepted: 2019.01.09; Published: 2019.01.30

\begin{abstract}
Introduction: To estimate the efficacy and safety of vascular endothelial growth factor receptor tyrosine kinase inhibitors (VEGFR-TKIs) in combination with chemotherapy for patients with advanced non-small cell lung cancer (NSCLC).

Methods: We searched PubMed, PMC database, EMBASE, EBSCO-Medline, Cochrane Central Register of Controlled Trials (CENTRAL), American Society of Clinical Oncology (ASCO), International Association for the Study of Lung Cancer (IASLC) and the European Society of Medical Oncology (ESMO), http://www.clinicaltrials.gov/, CNKI, and Wanfang databases to identify primary research reporting the survival outcomes and safety of VEGFR-TKIs in patients with advanced NSCLC. A meta-analysis was conducted to generate combined hazard ratios (HRs) with $95 \%$ confidence intervals (CI) for overall survival (OS), progression-free survival (PFS), objective response rate (ORR), disease control rate (DCR), and risk ratios (RRs) with $95 \% \mathrm{Cl}$ for adverse events (AEs).

Results: A total of 20 RCTs (8,366 participants) were included. The VEGFR-TKIs resulted in improved PFS (HR 0.82, 95\% Cl 0.78-0.87), ORR (HR 1.72, 95\% Cl 1.34-2.22), and DCR (1.45, 1.26-1.67) in patients with advanced NSCLC, but had no impact on OS (HR 0.94, 95\% Cl 0.89-1.00). The incidence of some high grade $(\geq 3)$ AEs increased, such as hemorrhage, hypertension and neutropenia.

Conclusions: Our study demonstrated that regimens with VEGFR-TKIs combined with chemotherapy improved PFS, ORR and DCR in patients with advanced NSCLC, but had no impact on OS. VEGFR-TKIs induced more frequent and serious AEs compared with control therapies.
\end{abstract}

Key words: VEGFR-TKIs, chemotherapy, efficacy, meta-analysis, non-small cell lung cancer, safety

\section{Introduction}

Lung cancer is the leading cause of cancer-related deaths worldwide, and is the primary cause of cancer deaths in men and the secondary cause in women ${ }^{1}$. Non-small cell lung cancer (NSCLC) is found in $80 \%$ of patients with lung cancer and $75 \%$ of patients are diagnosed at an advanced stage with a poor prognosis. Most patients with advanced NSCLC progress despite therapeutic intervention due to limited treatment success $2,3,4$. Platinum-based chemotherapy remains the standard treatment for NSCLC patients; however, epidemiologic studies suggest that its contribution has reached a therapeutic plateau ${ }^{5}$. Thus, new treatment strategies are required. Neovascularization of lung cancer plays an important role in cancer cell growth and metastasis ${ }^{6}$. Several vascular endothelial growth factor receptor tyrosine kinase inhibitors (VEGFR-TKIs) have shown clinical benefits when added to standard chemotherapy. During tumor development, the angiogenic switch is associated with the onset of expression and secretion of angiogenic factors by tumor cells. Neovasculature is crucial for 
the growth and survival of tumors larger than $3 \mathrm{~mm}^{3}$ in volume as it ensures the supply of oxygen and nutrients to cancer cells. In addition, it promotes metastasis by facilitating the entrance of tumor cells into the circulation system by fragile newly formed vessels7. VEGFR-TKIs inhibit the sprouting of vessels by blocking those activating signal pathways. Unlike classic cytotoxic drugs, VEGFR-TKIs have no direct cell-killing effect on lung cancer cells. It was shown in vitro that anti-VEGFR therapy contributes to normalization of tumor neovascular and enhances antitumor activity. VEGFR-TKIs in combination with chemotherapy results in cancer cell death and rapid tumor shrinkage ${ }^{8}$. However, whether VEGFR-TKIs in combination with chemotherapy can prolong survival and lower the number of adverse effects (AEs) requires further evaluation.

The use of VEGFR-TKIs in combination with chemotherapy as first-line or more than second-line agents for the treatment of patients with NSCLC has been evaluated, but the results on the efficacy and safety of such therapies are inconsistent. Nintedanib in combination with docetaxel is an effective second-line treatment for advanced lung adenocarcinoma in patients previously treated with first-line platinum-based therapy ${ }^{9,10,11}$. Axitinib showed promising single agent activity with an acceptable safety profile in an open label, single arm, phase II trial in advanced NSCLC ${ }^{12}$. Vandetanib, pazopanib, cediranib, and linifanib have also demonstrated higher efficiency when combined with chemotherapy in NSCLC ${ }^{13,14,15}$. However, some negative results have been observed following treatment with VEGFR-TKIs in combination with chemotherapy for advanced NSCLC patients. Motesanib combined with carboplatin-paclitaxel in non-squamous NSCLC, failed to provide an OS benefit, while demonstrating higher grade toxicity ${ }^{16}$. Sunitinib is a small oral TKI that targets VEGFR-1/2/3. In a controlled study, data analysis showed no benefit following treatment with sunitinib in unselected or non-squamous NSCLC patients ${ }^{17}$. Many clinical trials have demonstrated that VEGFR-TKIs with chemotherapy can improve survival outcomes in NSCLC patients. However, to date, nintedanib is the only VEGFR-TKI permitted by the USA and Europe for the treatment of advanced NSCLC. Many studies have reported no clinical benefits of VEGFR-TKIs when used in combination with chemotherapy ${ }^{18,19}$.

A previous meta-analysis showed that therapy consisting of chemotherapy plus VEGFR-TKIs has specific advantages over chemotherapy alone in terms of progression-free survival (PFS) and objective response rate (ORR), but the combination therapy did not prolong overall survival (OS) and disease control rate $(D C R)^{20}$. Thus, we performed an updated meta-analysis to summarize the efficacy and safety of VEGFR-TKIs in combination with chemotherapy for patients with advanced NSCLC.

\section{Methods}

\section{Literature search}

We searched PubMed, PMC database, EMBASE, EBSCO-Medline, Cochrane Central Register of Controlled Trials (CENTRAL), American Society of Clinical Oncology (ASCO), International Association for the Study of Lung Cancer (IASLC) and the European Society of Medical Oncology (ESMO), http://www.clinicaltrials.gov/, CNKI, Wanfang, and VIP databases using common keywords related to VEGFR-TKIs and NSCLC. The following keywords were included: VEGFR-TKI or vascular endothelial growth factor receptor tyrosine kinase inhibitors, lung cancer or NSCLC. We reviewed the bibliographies of relevant articles for additional publications.

\section{Selection criteria}

We included trials that met the following criteria: (i) the trial enrolled patients with cytologically or pathologically confirmed advanced NSCLC (males or females aged at least 18 years); (ii) the trial design was a randomized controlled trial (RCT) comparing VEGFR-TKIs in combination with chemotherapy with chemotherapy alone; (iii) the trial reported survival related outcomes, such as OS, PFS, ORR and DCR; (iv) the trial evaluated the safety of VEGFR-TKIs and reported AEs, such as hypertension, rash, nausea, vomiting, diarrhea, and neutropenia.

\section{Data extraction and quality evaluation}

Two independent investigators reviewed all the articles independently and discussed the articles until a consensus was reached. Data obtained from the studies included the first author, year of publication, patient source (region), type of study, number of patients, therapeutic regimen, survival outcomes, and safety data. The scale of risk of bias summary and risk of bias graph were used to assess the methodological quality of the included studies.

\section{Statistical analysis}

We chose OS and PFS as the endpoints in our meta-analysis. ORR and DCR are also summarized in Table 1. Safety outcomes were evaluated using STATA 14.0 (Stata Corp., College Station, TX, USA). HR was used as a measure of the prognostic value. Subgroup analyses were performed based on variables such as line of treatment. 
Publication bias was evaluated according to the funnel plot and Begg's and Egger's tests using Review Manager 5.3.5. Heterogeneity was assessed by the $\chi^{2}$ test and expressed by the $I^{2}$ index.

\section{Results}

\section{Characteristics of the included studies and risk of bias}

In total, 20 eligible studies with information on 8,366 patients were included in this meta-analysis. A flow chart of retrieval and selection of the studies is shown in Fig. 1. Table 1 summarizes the basic characteristics of the included studies. All 20 studies were double-blinded and allocation concealment was adequate in all studies. The risk of bias items for each included study are presented in Fig. 2.

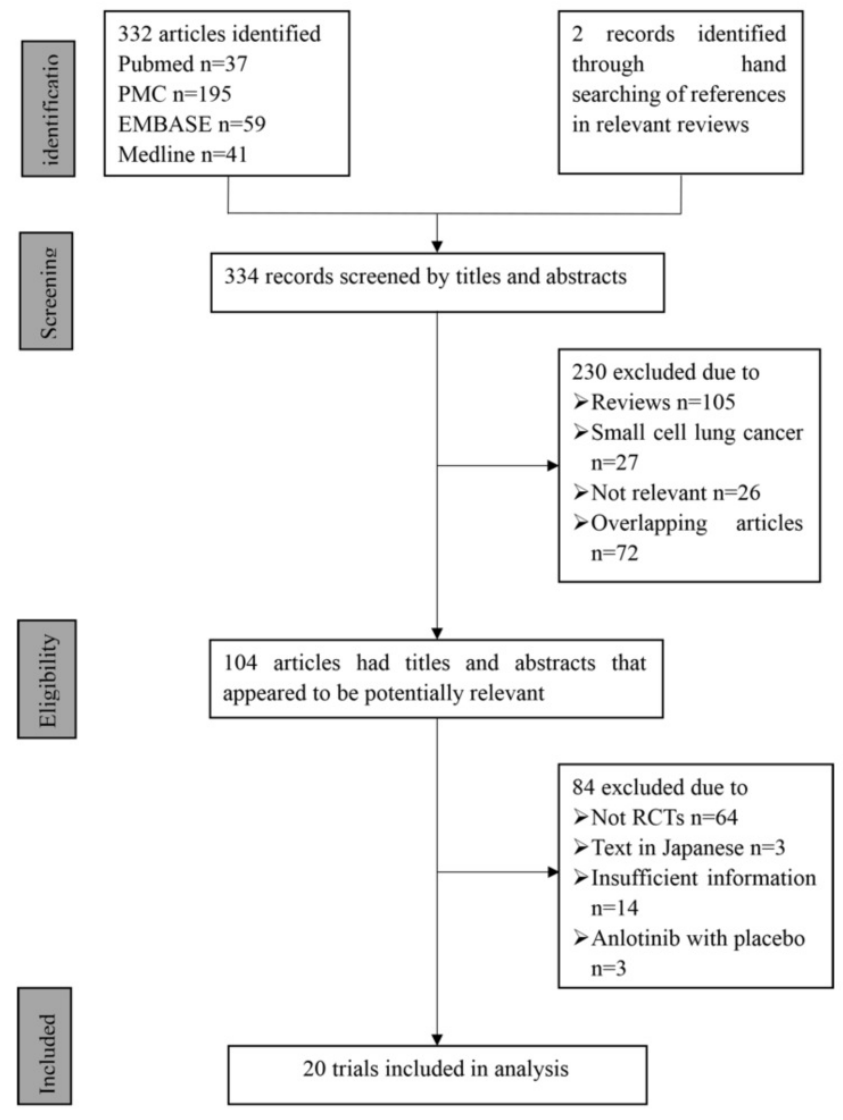

Fig. 1. Assessment of risk of bias based on the evaluation domains listed in the Cochrane Collaboration Risk of Bias Tool: risk of bias graph (A), risk of bias summary (B).

\section{Meta-analysis of survival outcome}

\section{Progression-free survival}

We identified 16 eligible trials ${ }^{11,16,17,18,21,22,23,24,25,26 \text {, }}$ 27,28,29,30,31,32, which included 8,092 patients, and investigated PFS following VEGFR-TKIs in combination with chemotherapy versus chemotherapy alone. Our meta-analysis revealed that
VEGFR-TKIs in combination with chemotherapy increased PFS compared with chemotherapy alone (HR, 0.82; 95\% CI, 0.78-0.87; $P<0.00001$, Fig. 3A). In the subgroup analyses, both first-line treatment $(\mathrm{HR}$, 0.83; 95\% CI, 0.77-0.89; $P<0.00001$, Fig. 4A) and more than second-line treatment $(\mathrm{HR}, 0.82 ; 95 \% \mathrm{CI}$, $0.76-0.88$; $P<0.00001$, Fig. 4B) prolonged PFS.

\section{Overall survival}

We identified 15 eligible trials $11,16,17,18,21,22,23,24,25,27$, 28,29,30,31,32, which included 7,379 patients, and investigated OS following VEGFR-TKIs in combination with chemotherapy versus chemotherapy alone. Our meta-analysis revealed that VEGFR-TKIs in combination with chemotherapy had no impact on OS compared with chemotherapy (HR, 0.94; 95\% CI, 0.89-1.00; $P=0.05$, Fig. 3B). In the subgroup analyses, neither first-line treatment (HR, 0.94; 95\% CI, 0.86-1.02; $P=0.13$, Fig. 4C) nor more than second-line treatment (HR, 0.94; 95\% CI, 0.86-1.03; $P=0.19$, Fig. 4D) prolonged OS.

\section{Overall response rate and disease control rate}

Thirteen trials reported the ORR $16,21,22,25,27,28,30,32,33,34,35,36,37,38$, and ten studies reported the DCR 22,25,27,31,32,33,34,35,36,37. Our meta-analysis revealed that VEGFR-TKIs in combination with chemotherapy prolonged ORR and DCR (HR, 1.72; 95\% CI, 1.34-2.22; $P<0.0001$, Fig. 3C; HR, 1.45; 95\% CI, 1.26-1.67; $P<0.00001$, Fig. 3D, respectively). In the subgroup analyses, both first-line treatment (HR, 1.45; 95\% CI, 1.29-1.64; $P<0.00001$, Fig. 4E) and second-line treatment $(\mathrm{HR}, 1.60 ; 95 \% \mathrm{CI}, 1.31-1.94 ; P<$ 0.00001 , Fig. 4F) prolonged the ORR. In addition, only second-line treatment (HR, 1.29; 95\% CI, 1.00-1.26; $P<$ 0.00001 , Fig. $4 \mathrm{H})$ rather than first-line treatment $(\mathrm{HR}$, 1.04; 95\% CI, 0.93-1.17; $P=0.47$, Fig. 4G) improved the DCR.

\section{Safety outcomes}

The safety results related to the use of VEGFR-TKIs in combination with chemotherapy for NSCLC patients in all 20 studies are shown in Fig. 5. Patients treated with VEGFR-TKIs in combination with chemotherapy were found to have more high grade $(\geq 3)$ AEs. Hemorrhage (RR, 8.32; 95\% CI, 3.84-18.04; $P=0.000)$, hypertension (RR, $4.77 ; 95 \% \mathrm{CI}$, 2.85-7.97; $P=0.000)$, neutropenia (RR, $1.26 ; 95 \% \mathrm{CI}$, 1.11-1.44; $P=0.000)$, $\operatorname{rash}(\mathrm{RR}, 6.31 ; 95 \% \mathrm{CI}, 4.05-9.84$; $P=0.000)$, vomiting $(\mathrm{RR}, 1.26 ; 95 \% \mathrm{CI}, 1.11-1.44 ; P=$ 0.000 ), and diarrhea (RR, 2.52; 95\% CI, 1.88-3.39; $P=$ 0.000 ) were significantly increased in NSCLC patients treated with VEGFR-TKIs in combination with chemotherapy. The risk of anemia, nausea, and constipation were comparable between the two groups (RR, 0.80; 95\% CI, 0.60-1.07; RR, 1.04; 95\% CI, 
0.67-1.62; RR, 1.18; 95\% CI, 0.40-3.50, respectively).

The RRs of all high grade $(\geq 3)$ AEs are summarized in Fig. 5.

\section{Publication bias}

There was no evidence of publication bias following assessment by funnel plot, Egger's test $(P>$ $0.05)$ and Begg's test $(P>0.05)$.

Table 1. Eligible clinical studies for clinical meta-analysis and their characteristics

\begin{tabular}{|c|c|c|c|c|c|c|c|c|c|c|c|}
\hline Author & Agents & Year & Country & $\begin{array}{l}\text { Line of } \\
\text { treatment }\end{array}$ & Phase & Regimens & $\begin{array}{l}\text { Number } \\
\text { of } \\
\text { patients }\end{array}$ & Median OS (months) & $\begin{array}{l}\text { Median PFS } \\
\text { (months) }\end{array}$ & $\begin{array}{l}\text { ORR } \\
\text { (percentage) }\end{array}$ & $\frac{\mathrm{DCR}}{\text { (percentage) }}$ \\
\hline \multirow[t]{2}{*}{ Luis Paz-Ares } & Sorafenib & 2012 & Spain & First & III & $\begin{array}{l}\text { Sorafenib + gemcitabine } \\
+ \text { cisplatin vs. }\end{array}$ & 385 & 12.4 & 6 & 27.8 & 62.1 \\
\hline & & & & & & placebo & 387 & $\begin{array}{l}12.5 \\
(\text { HR } 0.98, P=0.401)\end{array}$ & $\begin{array}{l}5.5 \\
(\mathrm{HR} 0.83, P= \\
0.008)\end{array}$ & $\begin{array}{l}25.8 \\
(P=0.11)\end{array}$ & $\begin{array}{l}63.1 \\
(P=0.47)\end{array}$ \\
\hline \multirow[t]{4}{*}{ Giorgio Scagliotti } & Sorafenib & 2010 & Italy & First & III & $\begin{array}{l}\text { Sorafenib + paclitaxel + } \\
\text { carboplatin vs. }\end{array}$ & 464 & 10.7 & 4.6 & & \\
\hline & & & & & & $\begin{array}{l}\text { placebo }+ \text { paclitaxel }+ \\
\text { carboplatin }\end{array}$ & 462 & 10.6 & 5.4 & & \\
\hline & & & & & & & & (HR 1.15, 95\% CI & (HR 0.99, 95\% CI & & \\
\hline & & & & & & & & $0.94-1.41, P=0.915)$ & $\begin{array}{l}0.84-1.16, P= \\
0.433)\end{array}$ & & \\
\hline \multirow[t]{3}{*}{ Yan Wang } & Sorafenib & 2011 & China & First & NR & $\begin{array}{l}\text { Sorafenib + gemcitabine } \\
+ \text { cisplatin vs. }\end{array}$ & 18 & 18 & 5 & 55.6 & 88.9 \\
\hline & & & & & & $\begin{array}{l}\text { placebo + gemcitabine } \\
+ \text { cisplatin }\end{array}$ & 12 & 18 & 4 & 41.7 & 100 \\
\hline & & & & & & & & $(P=0.68)$ & $(P=0.750)$ & $(P=0.905)$ & \\
\hline \multirow[t]{3}{*}{ Lihong Zhang } & Sorafenib & 2014 & China & First & NR & $\begin{array}{l}\text { Sorafenib + gemcitabine } \\
+ \text { cisplatin vs. }\end{array}$ & 12 & 12.8 & 7.4 & 33.3 & 75 \\
\hline & & & & & & $\begin{array}{l}\text { placebo + gemcitabine } \\
+ \text { cisplatin }\end{array}$ & 17 & 12.7 & 4.3 & 11.8 & 88.2 \\
\hline & & & & & & & & $(P=0.369)$ & $(P=0.070)$ & $(P=0.172)$ & $(P=0.234)$ \\
\hline \multirow[t]{3}{*}{ John V. Heymach } & Vandetanib & 2008 & Spain & First & II & $\begin{array}{l}\text { Vandetanib + paclitaxel } \\
\text { + carboplatin vs. }\end{array}$ & 56 & & 6 & & \\
\hline & & & & & & $\begin{array}{l}\text { placebo }+ \text { paclitaxel }+ \\
\text { carboplatin }\end{array}$ & 52 & & 5.75 & & \\
\hline & & & & & & & & $\begin{array}{l}\text { (HR 1.15, 95\% CI, } \\
0.75-1.77)\end{array}$ & $\begin{array}{l}\text { (HR 0.76, 95\% CI, } \\
0.51-1.14 \text { ) }\end{array}$ & & \\
\hline \multirow[t]{3}{*}{ John V. Heymach } & Vandetanib & 2007 & Spain & Second & II & $\begin{array}{l}\text { Vandetanib + docetaxel } \\
\text { vs. }\end{array}$ & 42 & 13.1 & 4.7 & & \\
\hline & & & & & & placebo + docetaxel & 41 & 13.4 & 3 & & \\
\hline & & & & & & & & $\begin{array}{l}\text { (HR 0.91, 95\% CI, } \\
0.55-1.52, \mathrm{P}=0.0361)\end{array}$ & $\begin{array}{l}(\mathrm{HR} 0.64,95 \% \mathrm{CI}, \\
0.38-1.05, \mathrm{P}= \\
0.037)\end{array}$ & & \\
\hline \multirow[t]{3}{*}{ Prof Roy Herbst } & Vandetanib & 2011 & USA & Second & III & $\begin{array}{l}\text { Vandetanib + docetaxel } \\
\text { vs. }\end{array}$ & 694 & 10.3 & 4 & 17 & \\
\hline & & & & & & docetaxel & 697 & 9.9 & 3.2 & 10 & \\
\hline & & & & & & & & $\begin{array}{l}\text { (HR 0.91, 97.52\% CI } \\
0.78-1.07, P<0.0001)\end{array}$ & $\begin{array}{l}(\text { HR } 0.79,97.58 \% \\
\text { CI } 0.70-0.90, P \\
<0.0001)\end{array}$ & $(P=0.0001)$ & \\
\hline \multirow[t]{3}{*}{$\begin{array}{l}\text { Richard H. de } \\
\text { Boer }\end{array}$} & Vandetanib & 2011 & Australia & Second & III & $\begin{array}{l}\text { Vandetanib + } \\
\text { pemetrexed vs. }\end{array}$ & 256 & 10.5 & 4.1 & 19 & 57 \\
\hline & & & & & & placebo + pemetrexed & 278 & 9.2 & 2.8 & 8 & 46 \\
\hline & & & & & & & & $\begin{array}{l}(\mathrm{HR} 0.86,97.54 \% \mathrm{CI} \\
0.65-1.13, P=0.219)\end{array}$ & $\begin{array}{l}(\text { HR } 0.86,97.58 \% \\
\text { CI 0.69-1.06, P = } \\
0.108)\end{array}$ & $(P<0.001)$ & $(P=0.0116)$ \\
\hline \multirow[t]{2}{*}{ Gridelli } & Vandetanib & 2014 & Italy & First & II & $\begin{array}{l}\text { Vandetanib + } \\
\text { gemcitabine vs. }\end{array}$ & 61 & 8.7 & 6.1 & 15 & 72 \\
\hline & & & & & & placebo + gemcitabine & 63 & 10.2 & 5.6 & 13 & 67 \\
\hline \multirow[t]{3}{*}{ Martin Reck } & Nintedanib & 2014 & Germany & Second & III & $\begin{array}{l}\text { Nintedanib + docetaxel } \\
\text { vs. }\end{array}$ & 655 & 10.1 & 3.4 & 35.1 & 73.6 \\
\hline & & & & & & placebo + docetaxel & 659 & 9.1 & 2.7 & 30.1 & 68.3 \\
\hline & & & & & & & & $\begin{array}{l}\text { (HR 0.94, 95\% CI } \\
0.83-1.05, P=0.2720)\end{array}$ & $\begin{array}{l}(\mathrm{HR} 0.79,95 \% \mathrm{CI} \\
0.68-0.92, P= \\
0.0019)\end{array}$ & & \\
\hline \multirow[t]{3}{*}{ Hanna } & Nintedanib & 2013 & Germany & Second & III & $\begin{array}{l}\text { Nintedanib + } \\
\text { pemetrexed vs. }\end{array}$ & 353 & & 4.4 & 9 & 61 \\
\hline & & & & & & placebo + pemetrexed & 360 & & 3.6 & 9 & 53 \\
\hline & & & & & & & & & $\begin{array}{l}\text { (HR 0.83, 95\% CI } \\
0.70-0.99)\end{array}$ & & \\
\hline \multirow[t]{3}{*}{ Chandra P Belani } & Axitinib & 2014 & USA & First & II & $\begin{array}{l}\text { Axitinib + PEM + DDP } \\
\text { vs. }\end{array}$ & 55 & 17 & 8 & 45.5 & \\
\hline & & & & & & PEM + DDP & 57 & 15.9 & 7.1 & 26.3 & \\
\hline & & & & & & & & $\begin{array}{l}\text { (HR 1.05, 95\% CI, } \\
0.65-1.69, \mathrm{P}=0.58)\end{array}$ & $\begin{array}{l}\text { (HR 0.89, 95\% CI, } \\
0.56-1.42, \mathrm{P}=\end{array}$ & & \\
\hline
\end{tabular}




\begin{tabular}{|c|c|c|c|c|c|c|c|c|c|c|c|}
\hline \multirow[t]{2}{*}{ Author } & \multirow[t]{2}{*}{ Agents } & \multirow[t]{2}{*}{ Year } & \multirow[t]{2}{*}{ Country } & \multirow[t]{2}{*}{$\begin{array}{l}\text { Line of } \\
\text { treatment }\end{array}$} & \multirow[t]{2}{*}{ Phase } & \multirow[t]{2}{*}{ Regimens } & $\begin{array}{l}\text { Number } \\
\text { of } \\
\text { patients }\end{array}$ & Median OS (months) & \multirow[t]{2}{*}{$\begin{array}{l}\text { Median PFS } \\
\text { (months) }\end{array}$} & \multirow[t]{2}{*}{$\frac{\text { ORR }}{\text { (percentage) }}$} & \multirow[t]{2}{*}{$\begin{array}{l}\text { DCR } \\
\text { (percentage) }\end{array}$} \\
\hline & & & & & & & & & & & \\
\hline \multirow[t]{3}{*}{ Giorgio Scagliotti } & pazopanib & 2013 & Italy & First & II & $\begin{array}{l}\text { pazopanib+ PEM + } \\
\text { DDP vs. }\end{array}$ & 62 & & & 14 & 27 \\
\hline & & & & & & PEM + DDP & 35 & & & 12 & 26 \\
\hline & & & & & & & & $\begin{array}{l}\text { (HR 1.22, 95\% CI, } \\
0.64-2.33, P=0.5519)\end{array}$ & $\begin{array}{l}(\mathrm{HR} 0.75,95 \% \mathrm{CI}, \\
0.43-1.28, \mathrm{P}= \\
0.2647)\end{array}$ & & \\
\hline \multirow[t]{3}{*}{ S.A. Laurie } & cediranib & 2014 & Canada & First & III & $\begin{array}{l}\text { cediranib + carboplatin } \\
+ \text { paclitaxel vs. }\end{array}$ & 151 & 12.2 & 5.5 & & \\
\hline & & & & & & carboplatin + paclitaxel & 153 & 12.1 & 5.5 & & \\
\hline & & & & & & & & $\begin{array}{l}\text { (HR 0.94, 95\% CI, } \\
0.69-1.30, \mathrm{P}=0.72 \text { ) }\end{array}$ & $\begin{array}{l}\text { (HR 0.91, 95\% CI, } \\
0.71-1.18, \mathrm{P}=0.49 \text { ) }\end{array}$ & & \\
\hline \multirow[t]{3}{*}{$\begin{array}{l}\text { Glenwood D. } \\
\text { Goss }\end{array}$} & cediranib & 2010 & Canada & First & II/III & $\begin{array}{l}\text { Cediranib + carboplatin } \\
+ \text { paclitaxel vs. }\end{array}$ & 126 & 10.5 & 5.6 & & \\
\hline & & & & & & carboplatin + paclitaxel & 125 & 10.1 & 5 & & \\
\hline & & & & & & & & $\begin{array}{l}\text { (HR 0.78, 95\% CI, } \\
0.57-1.06, P= \\
0.11)\end{array}$ & $\begin{array}{l}\text { (HR 0.77, 95\% CI, } \\
0.56-1.08, P= \\
0.13)\end{array}$ & & \\
\hline \multirow[t]{3}{*}{ Grace K. Dy } & cediranib & 2013 & USA & First & II & $\begin{array}{l}\text { Cediranib + carboplatin } \\
+ \text { gemcitabine vs. }\end{array}$ & 58 & 12 & 6.3 & 19 & \\
\hline & & & & & & $\begin{array}{l}\text { carboplatin + } \\
\text { gemcitabine }\end{array}$ & 29 & 9.9 & 4.5 & 20 & \\
\hline & & & & & & & & $\begin{array}{l}\text { (HR 0.66, 95\% CI, } \\
0.41-1.08)\end{array}$ & $\begin{array}{l}\text { (HR 0.69, 95\% CI, } \\
0.43-1.09)\end{array}$ & & \\
\hline \multirow[t]{3}{*}{ Ramalingam } & Linifanib & 2015 & USA & First & II & $\begin{array}{l}\text { Linifanib + carboplatin } \\
+ \text { paclitaxel vs. }\end{array}$ & 44 & 11.4 & 8.3 & & 43 \\
\hline & & & & & & $\begin{array}{l}\text { placebo }+ \text { carboplatin }+ \\
\text { paclitaxel }\end{array}$ & 47 & 11.3 & 5.4 & & 26 \\
\hline & & & & & & & & (HR 1.08) & (HR 0.51) & & \\
\hline \multirow[t]{3}{*}{ Heist } & Sunitinib & 2014 & USA & Second & II & $\begin{array}{l}\text { Sunitinib + pemetrexed } \\
\text { vs. }\end{array}$ & 41 & 6.7 & 3.7 & & \\
\hline & & & & & & pemetrexed & 42 & 10.5 & 4.9 & & \\
\hline & & & & & & & & $\begin{array}{l}\text { (HR 2.0, 95\% CI, } \\
1.2-3.2 \text { ) }\end{array}$ & $\begin{array}{l}\text { (HR 1.3, 95\% CI, } \\
0.9-2.1)\end{array}$ & & \\
\hline \multirow[t]{3}{*}{ Scagliotti } & Motesanib & 2012 & Italy & First & III & $\begin{array}{l}\text { Motesanib + carboplatin } \\
+ \text { paclitaxel vs. }\end{array}$ & 541 & 13.5 & 5.6 & 39 & \\
\hline & & & & & & $\begin{array}{l}\text { placebo }+ \text { carboplatin }+ \\
\text { paclitaxel }\end{array}$ & 549 & 11 & 5.4 & 25 & \\
\hline & & & & & & & & $\begin{array}{l}\text { (HR 0.88, 95\% CI, } \\
0.75-1.03 \text { ) }\end{array}$ & $\begin{array}{l}\text { (HR 0.78, 95\% CI, } \\
0.67-0.91 \text { ) }\end{array}$ & & \\
\hline \multirow[t]{3}{*}{ Kubota } & Motesanib & 2014 & Japan & First & III & $\begin{array}{l}\text { Motesanib + carboplatin } \\
+ \text { paclitaxel vs. }\end{array}$ & 110 & 20.9 & 7 & 62 & 91 \\
\hline & & & & & & $\begin{array}{l}\text { placebo }+ \text { carboplatin }+ \\
\text { paclitaxel }\end{array}$ & 117 & 14.5 & 5.3 & 27 & 77 \\
\hline & & & & & & & & $\begin{array}{l}\text { (HR 0.669, 95\% CI, } \\
0.473-0.946)\end{array}$ & $\begin{array}{l}\text { (HR 0.58, 95\% CI, } \\
0.42-0.79)\end{array}$ & & \\
\hline
\end{tabular}

Abbrevations: OS, overall survival; PFS, progression-free survival; ORR, objective response rate; DCR, disease control rate.

\section{Discussion}

Current treatment options for patients with advanced NSCLC are limited. Survival results and safety and tolerability findings are inconsistent in studies of various VEGFR-TKIs; thus, a statistical meta-analysis of these articles is needed. A particular focus in the treatment of NSCLC patients is survival outcome. Our results demonstrated that VEGFR-TKIs in combination with chemotherapy prolonged the PFS, ORR, and DCR, but had no impact on the OS. VEGFR-TKIs in combination with chemotherapy increased the incidence of some high grade $(\geq 3)$ AEs, such as hemorrhage, hypertension, neutropenia, rash, vomiting, and diarrhea. With regard to the line of treatment, the efficacy of VEGFR-TKIs in combination with chemotherapy may be different in the first-line and second-line settings. Significant PFS and ORR benefits were observed in both the first-line and second-line settings. DCR benefits were observed only in second-line treatment. However, there were no OS benefits either in the first-line or the second-line setting. A previous meta-analysis also showed no OS survival benefit ${ }^{20}$. It seems that although the VEGFR-TKIs have been proven to be effective in terms of the PFS, it was limited due to modest OS because of resistance during treatment. However, fibroblast growth factor (FGF) and platelet-derived growth factor (PDGF) have been found to be upregulated in patients exhibiting acquired resistance to anti-VEGF treatment and that the combination of VEGF/PDGF pathways has been proven to be more effective than single VEGF inhibition in animal models. The use of multi-targeted anti-angiogenesis TKIs in combination with chemotherapy seems to be a promising strategy for advanced NSCLC patients $39,40,41$. 


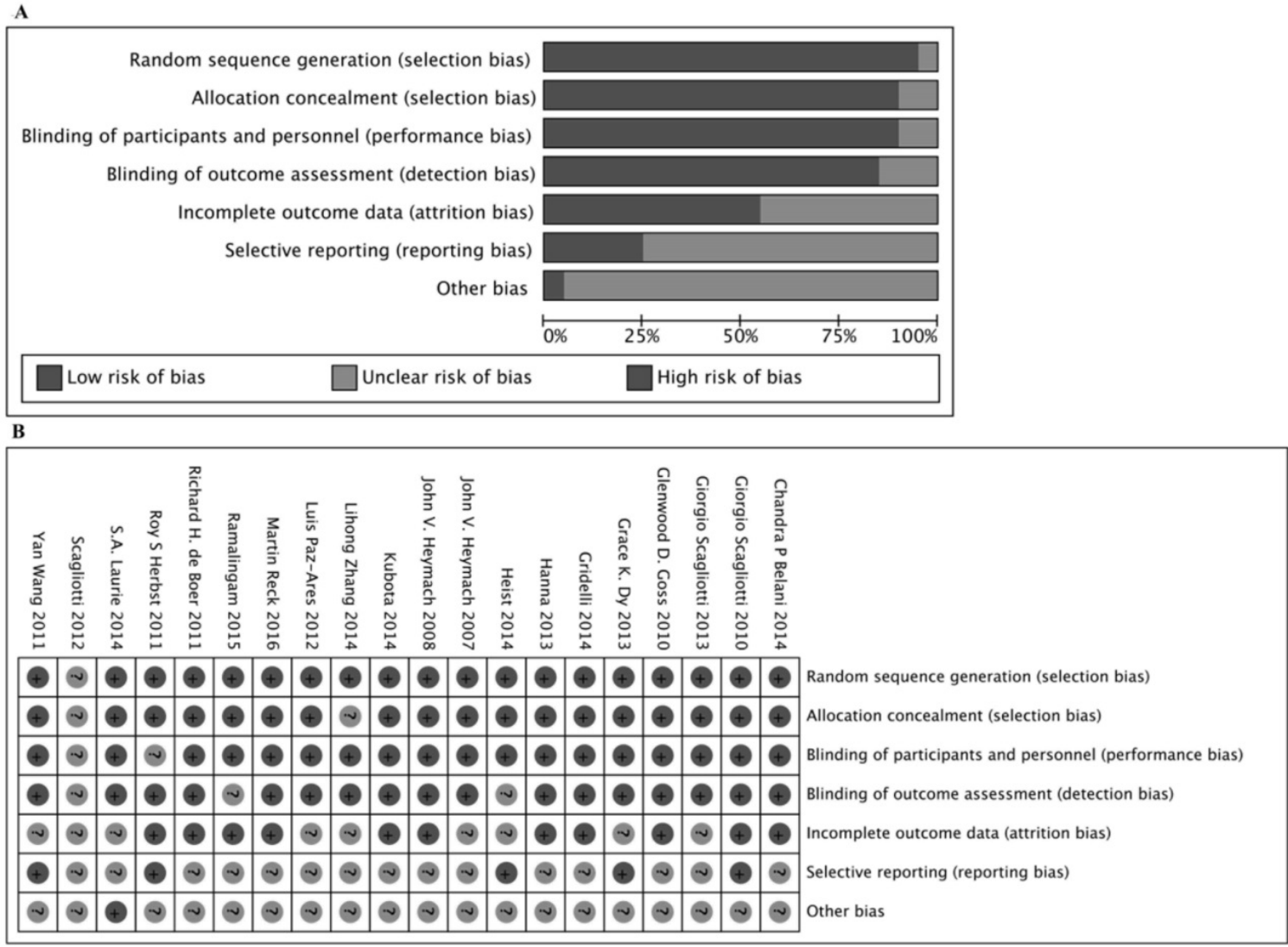

Fig. 2. Flowchart of computerized search and the eligible studies included in this systematic review and meta-analysis.

Several multi-targeted anti-angiogenesis TKIs, such as sorafenib, axitinib, cediranib, nintedanib, pazopanib, linifanib, motesanib are under clinical investigation and have not been approved for the treatment of patients with advanced NSCLC. The ZODIAC study demonstrated significant prolongation of PFS with vandetanib plus docetaxel versus docetaxel alone. This study showed that adding vandetanib significantly improved the ORR and delayed the time to worsening of lung cancer symptoms ${ }^{28}$. In the second-line setting of NSCLC, it was previously shown that the doublet combination of single cytotoxic agents and vandetanib, was safe and demonstrated antitumor activity ${ }^{11,42}$. Nintedanib improved the OS in a population of adenocarcinoma patients, particularly those with progression within 9 months after first-line treatment initiation ${ }^{26}$. In a phase II trial, first-line linifanib in combination with carboplatin-paclitaxel was associated with a higher ORR, PFS, and OS ${ }^{31}$. However, some clinical trials have reported negative results for VEGFR-TKIs in advanced NSCLC. Axitinib is a second-generation oral TKI of VEGF receptor 1, 2 and 3, PDGFR-b and c-kit, and has shown activity against several tumors. A phase II study evaluating the combination of axitinib with chemotherapy in non-squamous NSCLC not only failed to demonstrate a survival benefit, but also reported higher grade 3-4 toxicity ${ }^{21}$. Sorafenib, ceritinib, pazopanib, and motesanib also did not lead to a PFS or OS benefit in first-line treatment compared with chemotherapy alone $9,16,18,22,25,29$. Among the Chinese patients in phase II and phase III clinical trial, anlotinib appears to lead to prolonged overall survival and progression-free survival. Those findings suggest that anlotinib is well tolerated and is a potential third-line or further therapy for patients with advanced NSCLC $37,38,43$. However, our object was to evaluate VEGFR-TKIs and chemotherapy in comparison with chemotherapy. Thus, studies of anlotinib don't meet our inclusion criteria and are not included in our meta-analysis.

In our meta-analysis, VEGFR-TKIs in combination with chemotherapy improved the PFS, ORR and DCR in patients with advanced NSCLC, indicating that slowing disease progression also slowed symptom progression, leading to an important palliative benefit. This improvement in PFS, ORR, and DCR raises the possibility that patients with advanced NSCLC can live with fewer symptoms for a longer periods of time. However, there was no significant effect on the OS. EGFR expression, overexpression, and mutation have been implicated in the pathogenesis of NSCLC, suggesting that EGFR positive patients may derive increased clinical benefit 
from EGFR-targeted treatments. Thus, absence of the selection of EGFR positive patients may be a possible explanation for the negative results obtained for OS in patients treated with VEGFR-TKIs in combination with erlotinib. An accurate understanding of the expression levels and localization of drug targets in NSCLC is necessary to elucidate the mechanism of action of drugs in the clinic and, potentially, for identifying patients who would gain most clinical benefit from VEGFR-TKIs treatment. In addition, many patients received post-progression therapy, and although the number of patients and type of therapy received were balanced between groups before progression, the possibility that differences in response to post-progression therapy cannot be excluded.

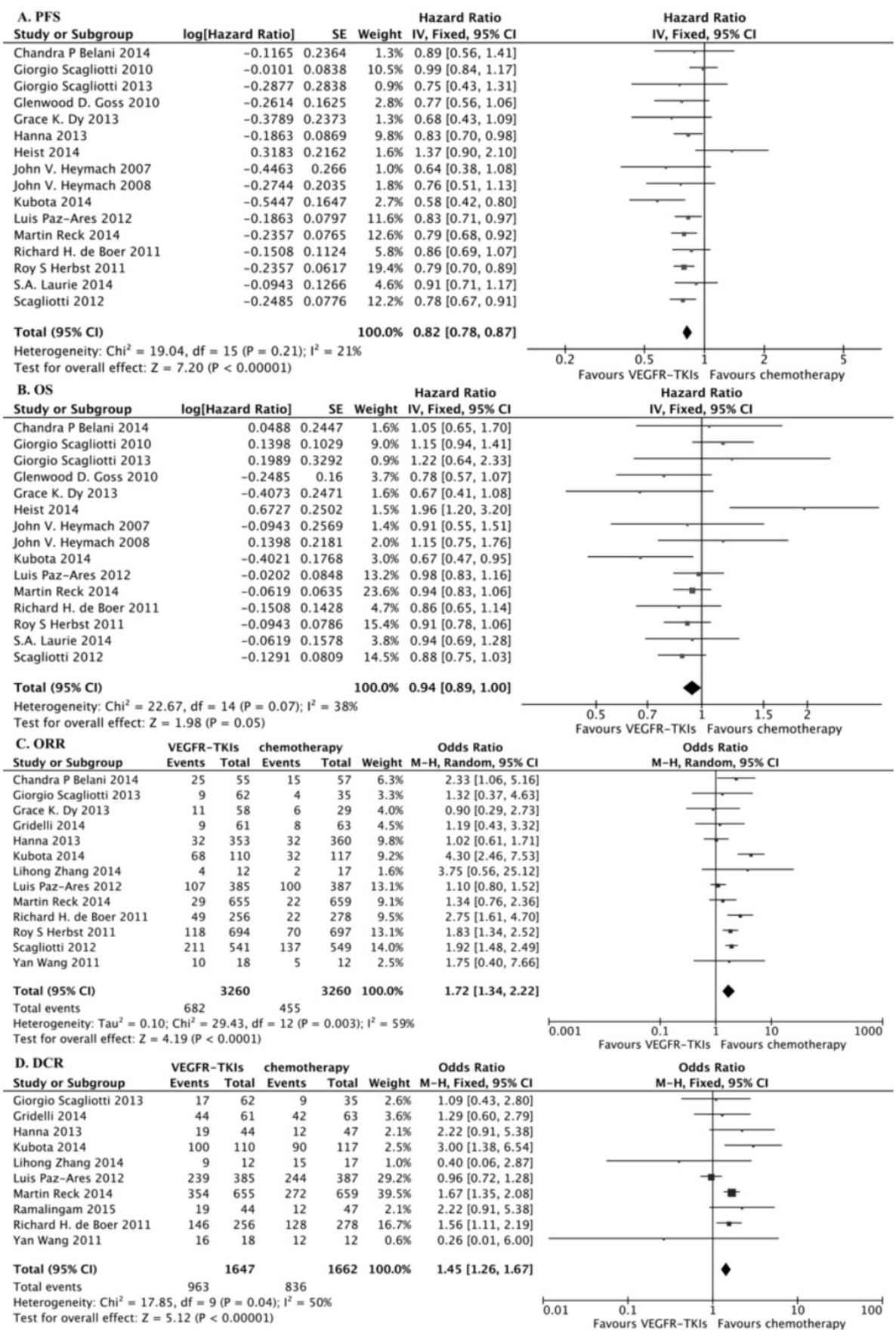

Fig. 3. Meta-analysis of PFS, OS, ORR and DCR. (A) Change in PFS between VEGFR-TKIs and chemotherapy: fixed-effects model. (B) Change in OS between VEGFR-TKIs and chemotherapy: fixed-effects model. (C) Change in ORR between VEGFR-TKIs and chemotherapy: random-effects model. (D) Change in DCR between VEGFR-TKIs and chemotherapy: fixed-effects model. 


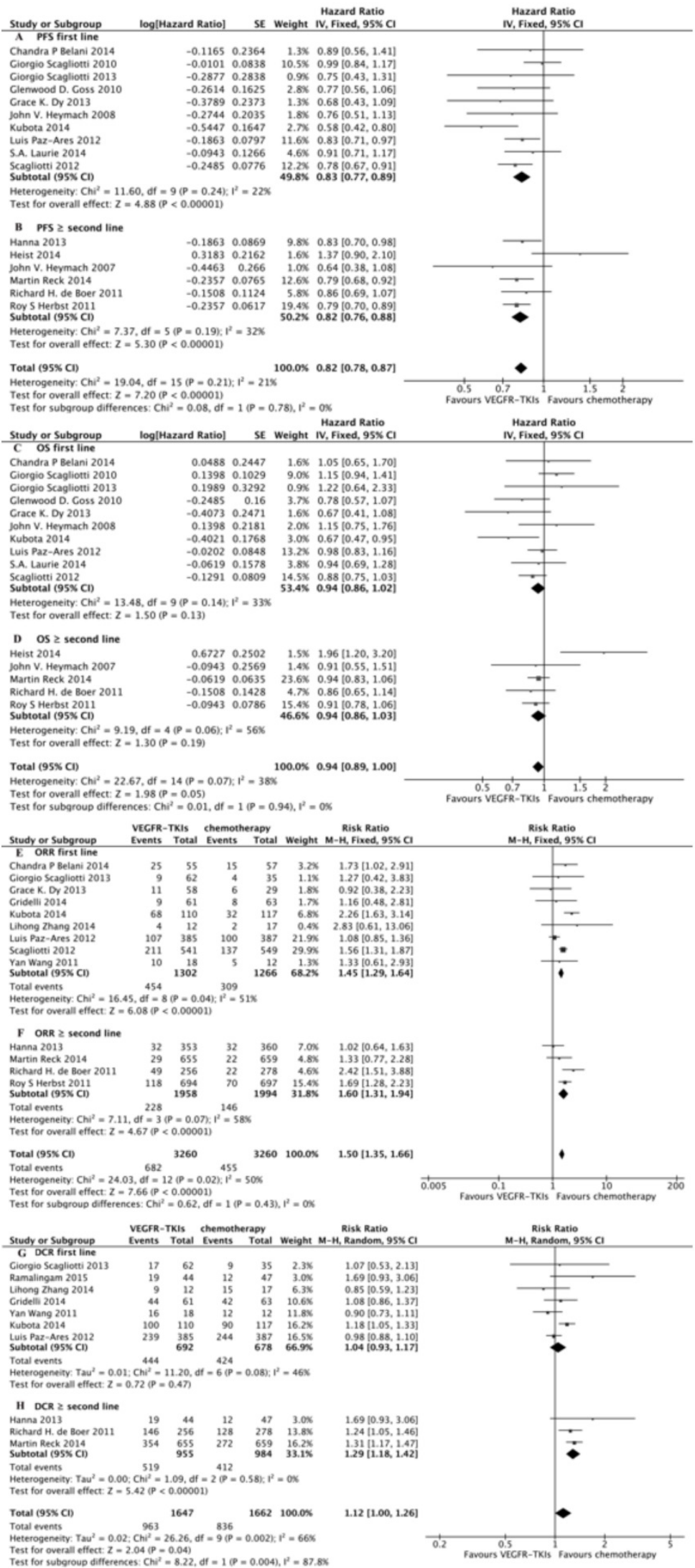

Fig. 4. Meta-analysis of subgroup. (A) Subgroup of first line of treatment on PFS between VEGFR-TKIs and chemotherapy: fixed-effects model. (B) Subgroup of second line of treatment on PFS between VEGFR-TKIs and chemotherapy: fixed-effects model. (C) Subgroup of first line of treatment on OS between VEGFR-TKIs and chemotherapy: fixed-effects model. (D) Subgroup of second line of treatment on OS between VEGFR-TKIs and chemotherapy: fixed-effects model. (E) Subgroup of first line of treatment on ORR between VEGFR-TKIs and chemotherapy: fixed-effects model. (F) Subgroup of second line of treatment on ORR between VEGFR-TKIs and chemotherapy: fixed-effects model. (G) Subgroup of first line of treatment on DCR between VEGFR-TKIs and chemotherapy: random-effects model. (H) Subgroup of second line of treatment on DCR between VEGFR-TKIs and chemotherapy: random-effects model. 


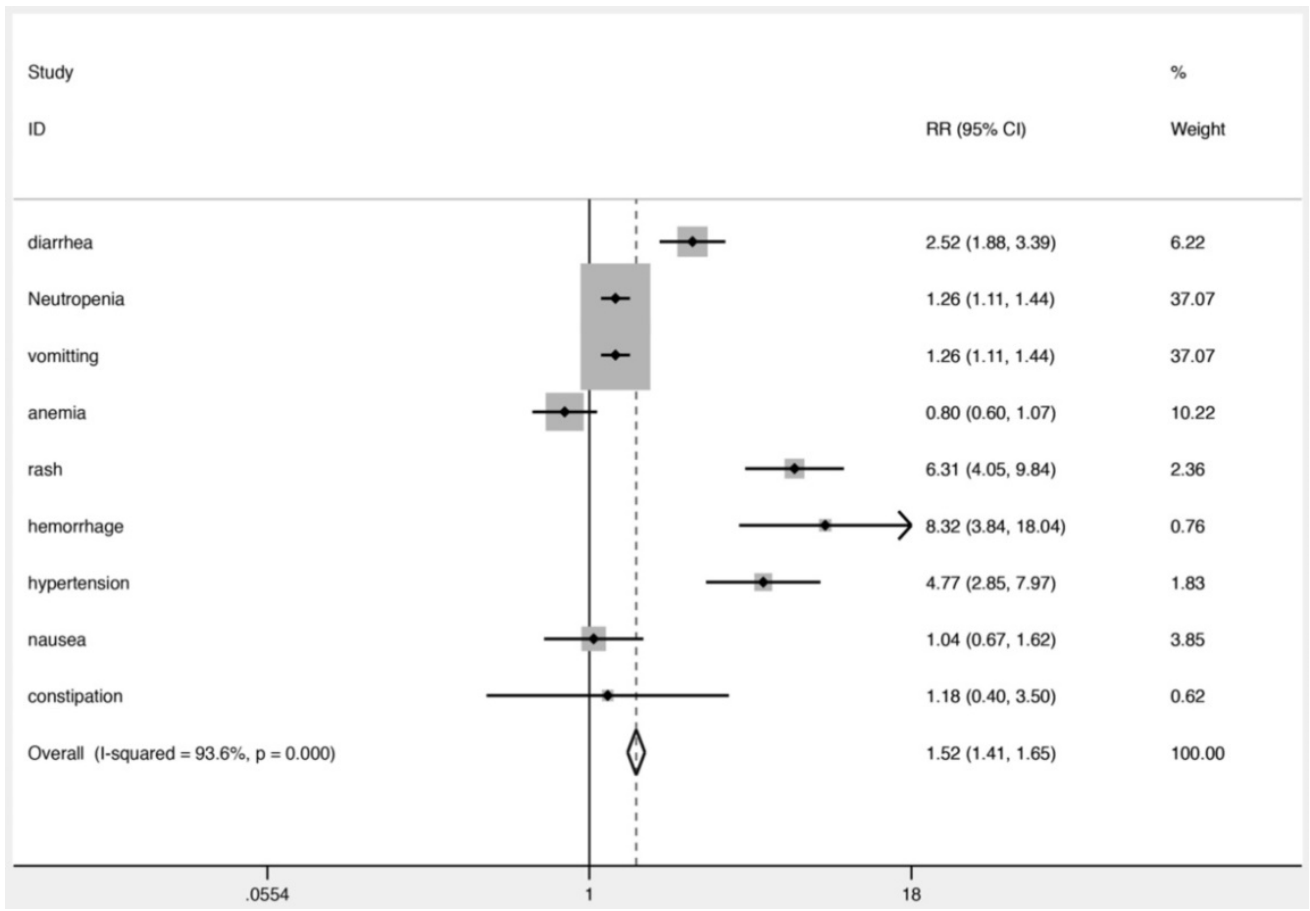

Fig. 5. RR of high grade adverse events in patients with advanced NSCLC treated with VEGFR-TKls.

Another focus of the treatment of NSCLC patients is safety and tolerability. VEGFR-TKIs in combination with chemotherapy resulted in more high grade ( $\geq 3$ ) AEs than chemotherapy alone, such as rash, hemorrhage, neutropenia, hypertension, and diarrhea. Hypertension is a well-known AE of VEGFR-TKIs. It is known that VEGFR-TKIs induce vasoconstriction by inhibiting flow-mediated dilation ${ }^{47}$. Interestingly, the occurrence of treatment-related hypertension is associated with the benefit of VEGFR-TKIs ${ }^{48}$. The VEGF signal pathway plays an important role in hematopoiesis. Therefore, VEGFR-TKIs may lead to neutropenia. Furthermore, the increased overall incidence of AEs probably reflects the additive effects of the drug combination, for example, the addition of vandetanib to docetaxel resulted in higher rates of grade 3-4 diarrhea, neutropenia, and rash ${ }^{28}$. In addition, another reason for these AEs may be the antiangiogenic effects in normal tissues that could destroy the network of capillaries in healthy lung tissues. VEGFR-TKIs change tumor vessel physiology, resulting in increased intratumoral uptake of drugs ${ }^{49}$. The body grows new blood vessels during wound healing, and as collateral circulation around blocked or atherosclerotic blood vessels. One concern is that VEGFR-TKIs may interfere with these normal processes, and worsen conditions such as coronary artery disease or peripheral artery disease. The risk of anemia, nausea, and constipation were comparable between the two groups. One possible explanation for this is the potential benefit of VEGFR-TKIs in reducing tumor growth. Another explanation might be the increase in erythropoietin induced by the antiangiogenic effect ${ }^{50}$. However, the mechanism has not been fully evaluated and further studies are required. In addition, the lower rate of treatment-related toxic effects indicated that the treatment was tolerable and manageable.

Our study has important limitations. Despite the RCT design, there were slight imbalances in sex and prior lines of therapy in the included trials. Differences between groups in the use of and response to post-progression therapies may confound the DCR and OS outcome. The outcome estimates were taken from published data; thus, systematic biases could not be minimized and the data in some cases were incomplete. Thus, further research should focus on high quality studies and clinical features in patients with comprehensive evaluation to obtain a more standardized study design and more accurate conclusions.

Clearly, there is an urgent need for a better understanding of the complex nature of tumor angiogenesis and how VEGFR-TKIs affect tumor vasculature and cellular components within the tumor microenvironment ${ }^{51}$.

\section{Conclusions}

The results of this meta-analysis showed that VEGFR-TKIs in combination with chemotherapy prolonged the PFS, ORR, and DCR in patients with advanced NSCLC, but had no impact on the OS. 


\section{Acknowledgements}

Thanks to the help of the members of the cancer center in Friendship Hospital of Capital Medical University.

\section{Availability of data and materials}

All data generated or analyzed during this study are included in this published article.

\section{Funding}

This work was supported by National Natural Science Foundation of China (No. 81774221), Basic-Clinical Cooperation Program from Capital Medical University (No.17JL14), The Capital Health Research and Development of Special (No. 2018-2-1113), Research Foundation of Beijing Friendship Hospital, Capital Medical University (No. yyqdkt2016-4).Beijing Municipal 215 High-level Health Person Foundation Project (No. 2014-3-004).

\section{Authors' contributions}

LL collected the references, analyzed the data and wrote the manuscript, JY modified and approved it. All authors read and approved the final manuscript.

\section{Competing Interests}

The authors have declared that no competing interest exists.

\section{References}

1. Torre LA, Bray F, Siegel RL, et al. Global cancer statistics, 2012. CA Cancer J Clin 65:87-108, 2015

2. Blanchard EM, Moon J, Hesketh PJ, et al. Comparison of platinum-based chemotherapy in patients older and younger than 70 years: an analysis of Southwest Oncology Group Trials 9308 and 9509. J Thorac Oncol. 2011;6: $115-20$

3. Delbaldo C, Michiels S, Rolland E, et al. Second or third additional chemotherapy drug for non-small cell lung cancer in patients with advanced disease. Cochrane Database Syst Rev. 2007; (4): CD004569.

4. Fossella F, Pereira JR, von Pawel J, et al. Randomized, multinational, phase III study of docetaxel plus platinum combinations versus vinorelbine plus cisplatin for advanced non-small-cell lung cancer: the TAX 326 study group. J Clin Oncol. 2003; 21:3016-24.

5. Zhong C, Liu H, Jiang L, et al. Chemotherapy plus best supportive care versus best supportive care in patients with non-small cell lung cancer: a meta-analysis of randomized controlled trials. PLoS One. 2013; 8:e58466.

6. Hanahan D, Weinberg RA. Hallmarks of cancer: the next generation. Cell. 2011; 144:646-74.

7. Pallis AG, Syrigos KN. Targeting tumor neovasculature in non-small-cell lung cancer. Crit Rev Oncol Hematol. 2013; 86:130-42.

8. Popat S, Mellemgaard A, Reck M, et al. Nintedanib plus docetaxel as second-line therapy in patients with non-small-cell lung cancer of adenocarcinoma histology: a network meta-analysis vs new therapeutic options. Future Oncol. 2017; 13:1159-1171.

9. Reck M, Kaiser R, Mellemgaard A, et al. Docetaxel plus nintedanib versus docetaxel plus placebo in patients with previously treated non-small-cell lung cancer (LUME-Lung 1): a phase 3, double-blind, randomised controlled trial. Lancet Oncol. 2014; 15:143-55.

10. Naumov GN, Nilsson MB, Cascone $T$, et al Combined vascular endothelial growth factor receptor and epidermal growth factor receptor (EGFR) blockade inhibits tumor growth in xenograft models of EGFR inhibitor resistance. Clin Cancer Res. 2009; 15:3484-94.

11. Heymach JV, Johnson BE, Prager D, et al. Randomized, placebo-controlled phase II study of vandetanib plus docetaxel in previously treated non small-cell lung cancer. J Clin Oncol. 2007; 25:4270-7.
12. Schiller JH, Larson $\mathrm{T}$, Ou SH, et al. Efficacy and safety of axitinib in patients with advanced non-small-cell lung cancer: results from a phase II study. J Clin Oncol. 2009; 27:3836-41.

13. Altorki N, Lane ME, Bauer T, et al. Phase II proof-of-concept study of pazopanib monotherapy in treatment-naive patients with stage I/II resectable non-small-cell lung cancer. J Clin Oncol. 2010; 28:3131-7.

14. Goodwin R, Ding K, Seymour L, et al. Treatment-emergent hypertension and outcomes in patients with advanced non-small-cell lung cancer receiving chemotherapy with or without the vascular endothelial growth factor receptor inhibitor cediranib: NCIC Clinical Trials Group Study BR24. Ann Oncol. 2010; 21:2220-6

15. Tan EH, Goss GD, Salgia R, et al. Phase 2 trial of Linifanib (ABT-869) in patients with advanced non-small cell lung cancer. J Thorac Oncol. 2011; 6:1418-25.

16. Scagliotti GV, Vynnychenko I, Park K, et al. International, randomized, placebo-controlled, double-blind phase III study of motesanib plus carboplatin/paclitaxel in patients with advanced nonsquamous non-small-cell lung cancer: MONET1. J Clin Oncol. 2012; 30:2829-36.

17. Heist RS, Wang X, Hodgson L, et al. CALGB 30704 (Alliance): A randomized phase II study to assess the efficacy of pemetrexed or sunitinib or pemetrexed plus sunitinib in the second-line treatment of advanced non-small-cell lung cancer. J Thorac Oncol. 2014; 9:214-21.

18. Scagliotti G, Novello S, von Pawel J, et al. Phase III study of carboplatin and paclitaxel alone or with sorafenib in advanced non-small-cell lung cancer. J Clin Oncol. 2010; 28:1835-42.

19. Ulahannan SV, Brahmer JR. Antiangiogenic agents in combination with chemotherapy in patients with advanced non-small cell lung cancer. Cancer Invest. 2011; 29:325-37.

20. Xiao YY, Zhan P, Yuan DM, et al. Chemotherapy plus multitargeted antiangiogenic tyrosine kinase inhibitors or chemotherapy alone in advanced NSCLC: a meta-analysis of randomized controlled trials. Eur J Clin Pharmacol. 2013; 69:151-9.

21. Belani CP, Yamamoto N, Bondarenko IM, et al. Randomized phase II study of pemetrexed/cisplatin with or without axitinib for non-squamous non-small-cell lung cancer. BMC Cancer. 2014; 14:290.

22. Scagliotti GV, Felip E, Besse B, et al. An open-label, multicenter, randomized, phase II study of pazopanib in combination with pemetrexed in first-line treatment of patients with advanced-stage non-small-cell lung cancer. J Thorac Oncol. 2013; 8:1529-37.

23. Goss GD, Arnold A, Shepherd FA, et al. Randomized, double-blind trial of carboplatin and paclitaxel with either daily oral cediranib or placebo in advanced non-small-cell lung cancer: NCIC clinical trials group BR24 study. J Clin Oncol. 2010; 28:49-55.

24. Heymach JV, Paz-Ares L, De Braud F, et al. Randomized phase II study of vandetanib alone or with paclitaxel and carboplatin as first-line treatment for advanced non-small-cell lung cancer. J Clin Oncol. 2008; 26:5407-15.

25. Paz-Ares LG, Biesma B, Heigener D, et al. Phase III, randomized, double-blind, placebo-controlled trial of gemcitabine/cisplatin alone or with sorafenib for the first-line treatment of advanced, nonsquamous non-small-cell lung cancer. J Clin Oncol. 2012; 30:3084-92.

26. Espinosa Bosch M, Asensi Diez R, Garcia Agudo S, et al. Nintedanib in combination with docetaxel for second-line treatment of advanced non-small-cell lung cancer; GENESIS-SEFH drug evaluation report. Farm Hosp. 2016; 40:316-27.

27. de Boer $\mathrm{RH}$, Arrieta $\mathrm{O}$, Yang $\mathrm{CH}$, et al. Vandetanib plus pemetrexed for the second-line treatment of advanced non-small-cell lung cancer: a randomized, double-blind phase III trial. J Clin Oncol. 2011; 29:1067-74

28. Herbst RS, Sun $Y$, Eberhardt WE et al. Vandetanib plus docetaxel versus docetaxel as second-line treatment for patients with advanced non-small-cell lung cancer (ZODIAC): a double-blind, randomised, phase 3 trial. Lancet Oncol. 2010; 11:619-26.

29. Laurie SA, Solomon BJ, Seymour L et al Randomised, double-blind trial of carboplatin and paclitaxel with daily oral cediranib or placebo in patients with advanced non-small cell lung cancer: NCIC Clinical Trials Group study BR29. Eur J Cancer. 2014; 50:706-12.

30. Dy GK, Mandrekar SJ, Nelson GD, et al. A randomized phase II study of gemcitabine and carboplatin with or without cediranib as first-line therapy in advanced non-small-cell lung cancer: North Central Cancer Treatment Group Study N0528. J Thorac Oncol. 2013; 8:79-88.

31. Ramalingam SS, Shtivelband M, Soo RA, et al. Randomized phase II study of carboplatin and paclitaxel with either linifanib or placebo for advanced nonsquamous non-small-cell lung cancer. J Clin Oncol. 2015; 33:433-41.

32. Kubota K, Ichinose Y, Scagliotti G, et al. Phase III study (MONET1) of motesanib plus carboplatin/paclitaxel in patients with advanced nonsquamous nonsmall-cell lung cancer (NSCLC): Asian subgroup analysis. Ann Oncol. 2014; 25:529-36.

33. Lihong Zhang, Qiang Fu, Guangyuan $\mathrm{Hu}$, et al. Sorafenib plus Chemotherapy for First-line Treatment of Non-small Cell Lung Cancer. Acta Medicinae Universitatis Scientiae et Technologiae Huazhong. 2014; 02:190-202.

34. Wei $\mathrm{Z}, \mathrm{Yu} \mathrm{W}$. The role of omega-3 polyunsaturated fatty acid in parenteral nutrion treatment of postoperative patients with cororectal carcinoma. Parenteral \& Enteral Nutrition. 2011; 3:002

35. Gridelli C, Novello S, Zilembo N, et al. Phase II randomized study of vandetanib plus gemcitabine or gemcitabine plus placebo as first-line 
treatment of advanced non-small-cell lung cancer in elderly patients. J Thorac Oncol. 2014; 9:733-7.

36. Wang Y, Wang L, Liu Y, et al. Randomize trial of cisplatin plus gemcitabine with either sorafenib or placebo as first-line therapy for non-small cell lung cancer. Chinese journal of lung cancer. 2011; 14:239-244.

37. Han B, Li K, Zhao Y, et al. Anlotinib as a third-line therapy in patients with refractory advanced non-small-cell lung cancer: a multicentre, randomised phase II trial (ALTER0302). Br J Cancer. 2018; 118:654-661.

38. Xiaoyan si HW, Xiaotong Zhang, et al. Efficacy and safety of anlotinib in 16 patients with advanced non-small cell lung cancer. Chinese Journal of Internal Medicine. 2018; 57( 11 ):830-834

39. Batchelor TT, Sorensen AG, di Tomaso E, et al. AZD2171, a pan-VEGF receptor tyrosine kinase inhibitor, normalizes tumor vasculature and alleviates edema in glioblastoma patients. Cancer Cell. 2007; 11:83-95.

40. Cabebe E, Wakelee H. Role of anti-angiogenesis agents in treating NSCLC: focus on bevacizumab and VEGFR tyrosine kinase inhibitors. Curr Treat Options Oncol. 2007; 8:15-27.

41. Casanovas O, Hicklin DJ, Bergers G, et al. Drug resistance by evasion of antiangiogenic targeting of VEGF signaling in late-stage pancreatic islet tumors. Cancer Cell. 2005; 8:299-309.

42. de Boer R, Humblet $Y$, Wolf J, et al. An open-label study of vandetanib with pemetrexed in patients with previously treated non-small-cell lung cancer. Ann Oncol. 2009; 20:486-91.

43. Han B, Li K, Wang $\mathrm{Q}$ et al. Effect of Anlotinib as a Third-Line or Further Treatment on Overall Survival of Patients With Advanced Non-Small Cell Lung Cancer: The ALTER 0303 Phase 3 Randomized Clinical Trial. JAMA Oncol. 2018; 4:1569-1575.

44. Shou $\mathrm{Y}$, Hirano $\mathrm{T}$, Gong $\mathrm{Y}$, et al. Influence of angiogenetic factors and matrix metalloproteinases upon tumour progression in non-small-cell lung cancer. Br J Cancer. 2001; 85:1706-12.

45. Song Y, Xue L, Du S, et al Caveolin-1 knockdown is associated with the metastasis and proliferation of human lung cancer cell line NCI-H460. Biomed Pharmacother. 2012; 66:439-47.

46. Ogino H, Yano S, Kakiuchi S, et al. Follistatin suppresses the production of experimental multiple-organ metastasis by small cell lung cancer cells in natural killer cell-depleted SCID mice. Clin Cancer Res. 2008; 14:660-7.

47. Steeghs N, Gelderblom H, Roodt JO, et al. Hypertension and rarefaction during treatment with telatinib, a small molecule angiogenesis inhibitor. Clin Cancer Res. 2008; 14:3470-6.

48. Lombardi G, Zustovich F, Farina P, et al. Hypertension as a biomarker in patients with recurrent glioblastoma treated with antiangiogenic drugs: a single-center experience and a critical review of the literature. Anticancer Drugs. 2013; 24:90-7.

49. Dickson PV, Hamner JB, Sims TL, et al. Bevacizumab-induced transient remodeling of the vasculature in neuroblastoma xenografts results in improved delivery and efficacy of systemically administered chemotherapy. Clin Cancer Res. 2007; 13:3942-50.

50. Alexandrescu DT, McClure R, Farzanmehr $\mathrm{H}$, et al. Secondary erythrocytosis produced by the tyrosine kinase inhibitors sunitinib and sorafenib. J Clin Oncol. 2008; 26:4047-8.

51. Joyce JA. Therapeutic targeting of the tumor microenvironment. Cancer Cell. 2005; 7:513-20. 